\title{
Changing Perspectives on Exchange Rates: Theory and Policy Implications
}

\author{
Perry Warjiyo ${ }^{1}$ \\ January 2006
}

\begin{abstract}
This paper reviews theoretical and empirical perspectives pertaining to the nature and impacts of exchange rate movements on macroeconomic conditions, and their fundamental ramifications on macroeconomic and monetary policies. In particular, we show that, with increasing speed and scope of financial globalization and cross-border capital flows, the view on exchange rate has been changing from trade flows to financial asset views. Exchange rate movements have been exhibiting greater volatility beyond fundamentals and often deviate from equilibrium, driven by factors such as shifts in risk premia, investor preferences, as well as underlying economic and financial conditions. Policy implications from such a changing perspective on exchange rate have been pervasive. Exchange rate has not been singled out as an instrument for increasing a country's external sector competitiveness in the modern literature of international finance. Rather, it constitutes an integral part of policy mix for coping with the impossible trinity of macroeconomic objectives in open economy, i.e. for benefiting from greater capital mobility while still maintaining stable exchange rate movements and domestic policy independence. The complete policy responses would include direct measures for stabilizing exchange rate, some forms of capital controls, and the implementation of inflation targeting framework of monetary policy.
\end{abstract}

JEL Classification Numbers: E5, F3, F4

Keywords: Monetary Policy, International Finance, Macroeconomic Aspects of International Trade and Finance

\section{Introduction}

The debate over the appropriate role of exchange rate as a policy instrument for macroeconomic stabilization policies has gained renewed interests in recent years. In the international forum, for example, as a part for adjustment mechanism for correcting the current global economic imbalances, the US has continued to pressure for greater exchange rate flexibility to the Asian countries, especially China and Malaysia. The

\footnotetext{
${ }^{1}$ Director of Economic Research and Monetary Policy, Bank Indonesia, and Lecturer at Department of Economics, University of Indonesia.
} 
conjecture is that some Asian countries manage their exchange rate movements for supporting their external competitiveness, thereby prevent the adjustment mechanisms through which global economic imbalances would have some impacts on their exchange rates and domestic economic performances. Even though the debate both theoretical and empirical ground on the merits of this issue continues, the US manage to enforce this issue as an integral part of international concerted efforts for adjustment mechanism of current global economic imbalances in various international forum.

For Indonesia, the debate over the role of exchange rate in the economy continues to upsurge every time there is heightened pressure on the rupiah. For example, when rupiah depreciates and fluctuates heavily such as during the period of March to June of 2004 and from March to August of 2005, proposals for introducing capital control or even moving to pegged or managed floating exchange rate system reemerge as short-cut measures for taming the instability of rupiah. Conversely, when the rupiah strengthens such as in the recent months of end 2005 and early 2006, worries about its impacts on export competitiveness of the country come to the fore. In general, it seems that the complete understanding of the nature and implications of exchange rate movements under free floating regime that Indonesia adopts since August 1997 has not been share broadly.

On both theoretical and empirical perspectives, our understanding of exchange rates and their impacts on macroeconomic stability has also been put under tests in the recent years for several reasons. With structural changes and advances in the financial markets, exchange rate movements become more volatile and proven to be very difficult to model and, especially, to forecast. There is evidence that the role of exchange rate for macroeconomic adjustments, especially for promoting current account balances, has dissipated as a country becomes more open and advances in its international trade and investments. There are also evidences that relationship between exchange rates, inflation and real activity has changed; in particular, with the apparent smaller passthrough of exchange rate changes into domestic prices. In addition, currency crises and changes in exchange rate regimes in emerging markets have brought to the fore the implications of foreign exchange balance-sheet mismatches for the link between the exchange rate and real economic activity.

In terms of the implications of exchange rates for macroeconomic and monetary policy, a number of questions are particularly relevant. Can exchange rate be used as an instrument for promoting export competitiveness, and thereby as a vehicle for correcting current account's imbalances? With greater openness in international trade and investments, how exchange rates response and are affected by capital flows and what their implications on the role of exchange rate for macroeconomic stability? What is the appropriate response of monetary policy to exchange rate changes, i.e. should it stabilize the exchange rate or should it respond only to the extent that exchange rate changes affect forecasts of inflation and output? What the implications of the impossible trinity between exchange rate stability, free capital mobility, and monetary policy independence to the practice of monetary policy making?

The objective of this paper is to review the changing theoretical perspectives and empirical findings on the nature of exchange rate movements and their on economic performances, and how these have some fundamental ramifications on the macroeconomic and monetary policies. As such, it complements a number of papers presented in this edition of the Bulletin which reports some empirical findings pertaining to the exchange rates in Indonesia. The first part of the paper focuses on the changing theoretical perspectives on exchange rate determination and how this has altered the 
interest on policy issues discussed in the literature. The second part of the paper is devoted to review empirical studies on the determinants of exchange rates and their impacts on trade balance, real output, and pass-through to inflation. With the reviews on both theoretical perspectives and empirical findings on the nature and impacts of exchange rate in the economy, the paper would then highlight some of perspectives on the alternative policy responses for promoting macroeconomic stability in open economy characterized by greater capital mobility and heighten exchange rate volatility.

\section{Theoretical perspectives on exchange rates}

Economists have long tried to explain what the level and factors driving the exchange rate movements, and how these affect economic performances and what the appropriate policy responses of a country. The general view is that no single theory can best explain exchange rate movements for all country and or for all period. The same is true for exchange rate policy that a country adopts. They will depend, among others, on the underlying economic structures, the regimes for exchange rate and foreign exchange, as well as the policy responses of the country. As such, a particular theory or policy may explain or work reasonably well for a country in a particular period but it may fail to do so when these factors are changing.

From the theoretical perspective, it seems that the way economists view on exchange rate determination is also changing. In the early thinking, based on the "law of one price' of balance of trade, the Purchasing Power Parity (PPP) exerts that, on the relative term, exchange rates reflect inflation differentials among countries. ${ }^{2}$ The concept is then widely used to measure Real Effective Exchange Rate (REER) for determining an equilibrium real exchange rate and its implication for short-run exchange rate misalignment and competitiveness. Nonetheless, only relative PPP seems to hold in the long-run while short-run deviations from PPP become common phenomena. Shifts in technology, tastes, commercial policies or labor force growth will structurally change national productivity and hence will permanently change the real exchange rate.

For explaining how exchange rate relates to other macroeconomic variables and what policy implications can be derived from it, the early model is mostly based on IS-LM curves and add those relationships considered relevant for an open economy through balance of payments relations with assumption of both PPP and IRP holds, such as in the neoclassical Mundell-Fleming model. The exchange rate appreciation or depreciation is thus determined by the surplus or deficit in the balance of payments. The analysis for policy response, however, depends on the regimes adopted for capital mobility and exchange rate. Under perfect capital mobility, for example, monetary policy has powerful effect on real output under flexible regime but not under fixed rate, while the converse is true for fiscal policy. Moreover, whether devaluation is followed by improvement in the current account would be depend on the relative elasticity of export and import to the real exchange rate changes, a condition that is referred to as MarshalLerner condition.

As the modern financial theory were developing in early 1970's, the economists views on exchange rate were shifting toward more from the financial perspective rather than trade relations for a number of reasons. ${ }^{3}$ First, with the breakdown of Breton Wood

\footnotetext{
${ }^{2}$ From the beginning, the PPP doctrine was related to a monetary interpretation of exchange rate, see, for example, Frenkel (1978), and Officer (1982).

${ }^{3}$ See, for example, Gartner (1978) and MacDonald (1988).
} 
system, more countries are adopting flexible exchange rate regimes with a fundamental implication to the increasing volatility of exchange rate. Second, with the unprecedented advances in cross-border capital flows following globalization, monetary and financial aspects have been the dominant factors put forward in the modern literature of international finance for explaining exchange rate volatility and policy implications that emerge from it. As such, the focus of thinking in both theory and policy has also shifted toward explaining exchange rate volatility, choice of exchange rate regime, benefits and costs of capital flows, financial crisis, and monetary policy response under flexible exchange rate regime.

With such a changing theoretical and policy perspectives, partial equilibrium of Interest Rate Parity (IRP) model based on arbitrage argument in the cross-border financial market has gained popularity for explaining short-run exchange rate movements. ${ }^{4}$ The asset model treats foreign exchange rates as assets traded in competitive markets, viewing differential in returns and risks of those assets as the key determinants of the exchange rate. ${ }^{5}$ Thus, the covered interested rate parity (CIRP) states that exchange rate reflects interest rate differential among countries after considering the inherent risks of financial assets traded between the countries. Even though CIRP is supported by many evidences, but different monetary policy, degree of risk aversion, political risks, barriers to capital mobility and market microstructure variations may cause persistent varying risk premia over time.

Similarly on macroeconomic perspectives of the exchange rate, in the late 1970's the basic paradigm of Mundell-Fleming model was seriously challenged in term of variable identification, treatment of expectations and econometric methodology. The modern asset views on exchange rate determination models in 1980's were designed to incorporate explicitly these issues. Under the Monetarist Model, for example, long-run exchange rate is perfectly correlated with the level of the relative money supply of a country to its major trading partners. ${ }^{6}$ In that case, neutrality of money to both price and exchange rate would hold in the long-run. Nonetheless, in the short-run where exchange rate expectation presents, such as under excessive money supply in an inflationary and/or high growth economy, this model explains why a foreign exchange rate market may be characterized by a self-fulfilling prophecy. Moreover, when the money supply becomes stochastic, volatility of exchange rate movements may be further exaggerated by incomplete information of the market players.

Domestic price rigidity may also explain short-run exchange rate volatility. In particular, when domestic money supply is excessive or a currency is devalued while the price of goods remains fixed for short-run (but not in the long-run) as in 'Sticky Price' Model (Dornbusch, 1976), the exchange rate movements may 'overshoot' against its long-run equilibrium level. Moreover, under a game-theoretic perspective with noncooperative and uncoordinated many players, there is no reason to believe everyone would share common information and act together to reach the desired long-run equilibrium exchange rate in a single step. A balance of payment crisis, according to this

\footnotetext{
${ }^{4}$ Perhaps the best known study concerning the validity of interest rate parity is that by Frankel and Levich (1975).

${ }^{5}$ The proponent of the asset approach (see, for example, Mussa, 1979) argue that one should use tools normally used for the determination of other asset prices (such as bond and share prices) in analyzing the determinants of exchange rates, rather than analyzing the exchange rate in terms of flow demand and flow supplies.

${ }^{6}$ See most standard textbooks in international finance (for example, Halliwood and MacDonald, 2000, Gartner, 1978, and MacDonald, 1988) for further details on the model.
} 
model, is thus a natural outcome of maximizing behavior by rational agents faced with a fundamental inconsistency between monetary and exchange rate policies. As such, transparency and good government coordination as a signal to the financial market becomes essential to achieve effective monetary policy for currency stabilization.

Short-run exchange rate volatility may also be caused by shifts in market preferences for holding financial assets of different currencies and asset qualities. Under Currency Substitution Model, exchange rate depreciation and volatility may shift preferences of holding money away from domestic currency, and it subsequently may put more pressures on the depreciation and volatility of exchange rate. ${ }^{7}$ Meanwhile, Portfolio-Balance Approach exerts that exchange rate reflects shifts in relative return and risk profile of different financial assets traded cross-border. ${ }^{8}$ As such, asset substitution effects and the nature of expectations formation on these short-run capital flows (rather than the trade flows) play dominant role in exchange rate determination. In general, the short-run movements of exchange rate and how the impact of policies to the exchange rate can be quite different from the long-run impact, depending on the return and risk profile of these financial assets as well as the nature of expectations. Exchange rates should implicitly behave like the behavior of asset prices in speculative markets.

\section{Determinants of exchange rates}

Explaining and forecasting exchange rate behavior is notoriously difficult, especially with growing number of countries adopting more flexible regimes and increasingly large and volatile cross-border capital flows. Not surprisingly, a number of different approaches have been proposed in modeling exchange rate behavior. A number of researches follow the literature on modeling exchange rate determination in the long-run that build on PPP conditions while others test the IRP along with efficient foreign exchange market hypothesis. Tests on different macroeconomic approaches for modeling exchange rate determination as elaborated in the preceding section have also been conducted. Moreover, in recent years a growing body of literature has presented empirical evidence on long-run exchange rate equilibrium concepts. One variant, the behavioral equilibrium exchange rate (BEER) approach, focuses on a number of plausible determinants, such as productivity, real interest rate differentials, government expenditure and net foreign assets. ${ }^{9}$ Another variant, the fundamental equilibrium exchange rate (FEER) approach, developed by Williamson (1994), combines low unemployment and low inflation with a sustainable desired net flow of resources.

How well the theoretical models and empirical approaches could explain exchange rate movements depend on the characteristic of economy and the period of study. Cheung, Chinn, and Pascual (2004), for example, reassess exchange rate prediction using a wider set of models that have been proposed in the literature, i.e. PPP, sticky price model, IRP, productivity differential model, and a variant of BEER model. The model performance is evaluated at forecast horizons of 1,4 , and 20 quarters, using the mean squared error, direction of change metrics, and the

\footnotetext{
${ }^{7}$ Girton and Roper (1981) were the first to use the term "currency substitution" to describe situations where agents hold more than one currency. For an ellaboration of the model of exchange rate under currency substitution, see, e.g., King et al (1977).

${ }^{8}$ Portfolio balance model has been applied to determination of the exchange rate by, among others, Isard (1978), and Dornsbusch and Fischer (1980).

${ }^{9}$ For an application of BEER model for exchange rate determination in Indonesia, see Kurniati and Hadiyanto (2002).
} 
"consistency" test. Overall, model, specification, and currency combinations that work well in one period do not necessarily work well in another period. Nonetheless, while the forecast of these models does not outperformed the random walk over the short-run horizon, their performances improve as forecast horizons lengthen when fundamental factors become more apparent in driving the exchange rate movements.

The important of fundamental factors in driving long-term exchange rate is also evidenced in the PPP relations. In an attempt to test the law of one price over the longrun, Rogoff, Froot and Kim (2001) examines annual commodity data from England and Holland oven span of seven centuries. They find that magnitude, volatility, and persistence of deviations from the law of one price have not declined as much as one expect despite lower transport costs, reduced tariff protection, and fewer wars and plaque in the modern era. Likewise, although flatly rejected in earlier research, arguably due to the low power of the tests employed, recent research (e.g., Edison et. al., 1997) is more favorable to PPP tested on long time spans or panels of industrialized countries. The literature has also highlighted that the relevance of PPP is limited to traded goods.

A large body of literature has rejected IRP along with efficient foreign exchange market hypothesis as forward rates exchange markets are found to be biased predictors of future spot rates, a finding known as "forward premium puzzle". This puzzle has been documented in a number of studies, and explained this with the existence of risk premia, changes in the long-run equilibrium exchange rate, and irrationality and learning of market players (Hodrick, 1987; Froot and Thaler, 1990, and Lewis, 1995). More recently, however, these explanations have been challenged, as models incorporating monetary policy reactions, different data sets, and new econometric specifications have been considered. Meredith and Ma (2003), for example, relates the bias of forward rates to the endogeneity of monetary policy, in that over the short-run shocks that cause the current exchange rate to depreciate also cause output and prices to rise, leading to higher interest rate responses. Over the longer horizons, however, the bias fades, as the shortrun correlation due to policy endogeneity declines relative to long-term relations that are consistent with IRP. The empirical findings that IRP holds better over the longer horizons could simply reflect the fact that inflation differentials between countries dominate nominal exchange rate movements over time.

At the other extreme, research has also focused on exchange rate behavior in the very short-run. This type of analysis typically looks at the role of "news", which are identified either statistically (as residuals in regressions that relate exchange rates to fundamentals) or survey data on expectations about various macroeconomic announcements. Galati and Ho (2001), for example, investigate to what extent daily movements in the euro/dollar rate were driven by news about macroeconomic situation in the US and the euro area during the first two years of EMU. They examine whether market participants reacted to news in different ways depending on whether the news came from the US or from the euro area, and whether the news were good or bad. They find that macroeconomic news have a statistically significant correlation with daily movements of the euro against the dollar. There are indications of asymmetric response, in that market seems to ignore good news and remain reacts to bad news as often claimed in market commentaries. ${ }^{10}$

\footnotetext{
${ }^{10}$ In more recent study, Ehrmann and Fratzscher (2004) analyze the link between economic fundamentals and exchange rates by investigating the importance of real-time data, and find that such economic news in the United States, Germany and the euro area have indeed been a driving force behind daily US dollar euro/DEM exchange rate developments in the period 1993-2003.
} 
In recent years, a new approach to modeling exchange rates which dwell into market microstructure has increasingly attracted attention. The approach focuses on information asymmetries and how dispersed information -about macroeconomic variables such as money demand, risk preferences, future inflation- is shared among market players. Dispersed information also includes information about actions of other market participants, i.e. about different trading responses to commonly observed data. In a series of papers, Lyons (2001) has presented empirical evidences suggesting that models that follow this approach fit the data fairly well. This conclusion is also supported by other papers (Sarno and Taylor, 2001).

For the case of Indonesia, Kurniati and Hadiyanto (2002) provide a reference for using BEER model for exchange rate determination. In particular, they underline the important of technical factors such as risk premium and net foreign asset in addition to fundamental factors such as inflation differential, term of trade, and economic growth for determining nominal exchange rate. In this edition of Buletin, Husman (2006a) examines further factors that determined the Indonesian rupiah against US dollar nominal exchange rate post crisis period. The effect of oil prices and the interaction of supply and demand in the foreign exchange market are included as part of explanatory variables besides other fundamentals, using an error correction model (ECM). The use of composite model that incorporates a number of familiar approaches in exchange rate determination is found to outperform model based on single approach in term of their forecast performance. The estimation results show that the increase in oil price will depreciate the rupiah exchange rate and that risk factor is the most important factor that influences the rupiah development.

Though none of those structural standard models is able to explain well all of the short-run dynamics of nominal exchange rate in all country for all period, some stylized facts and policy implications may be provided from their analysis. In particular, these models provide inferences for policy measures for addressing key fundamental factors driving exchange rate in the long-run, i.e. inflation, exchange rate, money supply, real output, as well as preferences in holding of currencies and financial assets. Nonetheless, exchange rate may exhibit short-run volatility from its fundamental level due to a number of reasons, e.g. productivity shocks, risk premia, stochastic money supply, inconsistency between monetary policy and exchange rate regime, and portfolio shifts and speculations in the financial market. As such, programs for exchange rate stabilization should thus be directed towards resolving both these fundamental factors as well as short-run volatility.

\section{Exchange rate and trade balance}

In the early (prior 1970's) literature, exchange rate is often viewed as an instrument for macroeconomic adjustment for correcting external imbalances. In particular, the conventional analysis suggests that a nominal devaluation affects the economy through two channels, i.e.: (i) as an expenditure-reducing policy, it reduces private spending and aggregate demand by raising the price level and lowering real money balances, and (ii) as an expenditure-switching policy, it influences the composition of output and domestic absorption between traded goods and non-traded goods. It is the relative effects of these two channels that determine how the exchange rate will be used as a combination with that of fiscal and monetary instruments for macroeconomic stability.

Analysis of the effects of exchange rates changes on the trade balances is often performed in a partial equilibrium framework, that is, by analyzing solely the effects of 
real exchange rate changes on export and import flows. With given levels of domestic prices and the foreign currency price of imports, a nominal devaluation will reflected solely on an increase in the relative price of exports to imports. Thus, for the trade balance to improve following a devaluation, the Marshall-Lerner condition must be met, i.e. sum of the elasticities of export supply and import demand with respect to real exchange rate changes must exceed unity. ${ }^{11}$

The Marshall-Lerner condition suggests that a key step in assessing the effect of exchange rate changes on the trade balance is to assess the sensitivity of trade flows to changes in relative prices. In practices, such attempts take the form of estimating econometrically equations of exports and import volumes to changes in relative prices and real economic activity either at home (for imports) or abroad (for exports). Although such equations have consistently been used in policy assessment and macroeconomic models, much of the empirical works in this area lacked precision in the determination of real exchange rate elasticities. ${ }^{12}$ The use of aggregated data on trade flows may obscure differences in behavior across different types of traded goods. Real exchange rate measures based on consumer prices may not reflect adequately movements in the price of tradable goods. In addition, changes in the trade policy regime or shifts in the types of traded goods over time may be important and are often inadequately captured in the estimation.

More recent studies have relied increasingly on co-integration analysis to emphasize the important of short- and long-run elasticities in assessing the effect of exchange rate on trade flows. For instance, Reinhart (1995) indicated that a long-run price elasticity of import demand is much higher than of export supply for Kenya, suggesting that the Marshall-Lerner condition is not satisfied, while the converse is evidenced in Columbia. In other study, Senhadji (1998) found that the short-term price elasticity for real imports for Nigeria is much lower than of the long-run, indicating there is a significant difference in the timing of responses of trade volumes to activity and relative price changes. Because a devaluation causes an unfavorable terms of trade response, with domestic currency value of import prices rising relative to export prices, its initial impact on nominal trade balance can be small or even may get worse initially before it gets any better. The expected effects may be become more apparent only in the medium-term. This particular phenomenon gives rise to the so-called J-Curve effect.

For the case of Indonesia, a number of papers published in this edition of Bulletin provide further evidences on the impacts of exchange rate to trade balances. Astiyah and Santoso (2006), for example, find that real exchange rate depreciation does not improve the performance of trade balance in the short-run, thus implise that MarshallLerner condition does not hold for Indonesia. For the long-run, the result also points out to the limited trade balance improvement as the positive impacts of real exchange rate depreciation to export volume is offseted by increas in imports. Husman (2006b), however, provides contrary evidences that Marshall-Lerner condition holds for Indonesia's trade balance with US, Japan, Korea, Taiwan, and Germany for the periode of 1993 - 2004. Nonetheless, the estimated coefficient of real exchange rate depreciation is relatively small, indicating that non-exchange rate factors have dominant

11 Marshall-Lerner condition is the common link between trade theory and international macroeconomics in a static world. It states that the condition for stability of the foreign exchange market depends directly in terms of the import and export elasticities of demand. These elasticities would determine the slopes of the currency supply and demand curves. See, more discussion by Levi [1990, pp. 118-120]. For a detailed derivation of the Marshall-Lerner condition, see Sodersten (1980).

${ }^{12}$ Agenor (2000) for more discussion on this issue. 
effects to trade balance, especially those of supply factors such as quality of product, rigidity and ineffficiency of production, and high import content. Moreover, there is no evidence for J-curve fenomena for agregate trade balance between Indonesia and its trading partners even though it exists for bilateral trade with Japan, Korea, and Germany. Arintoko dan Wijaya (2006) also finds weak evidence of a J-Curve for the Indonesia's current account. In fact these empirical results reject the J-Curve hypothesis. The empirical study finds little evidence that the currency depreciation causes the current account deficits in the short run in Indonesia-US bilateral data and no evidence of a reliable long run effect of exchange rate change on the current account.

Interestingly, these empirical results show that conflicting evidences on the impacts of exchange rate on trade balance that may not always consistent with the standard theoretical explanation of the Marshall-Lerner condition and the J-Curve, and thus pose a strong challenge for international economic theory and policy. A more general analysis of Marshall-Lerner condition can be derived from a complete macroeconomic model for assessing the effects of exchange rate changes on output, inflation, relative prices, government budget, and trade balance. Of particular important is how this analysis can be altered with the role of imported intermediate goods in the production process, as is often the case in developing countries. In some countries, the share of energy and non-energy intermediate imports can exceed three-fifths of total import (Agenor, 2000). Through the cost of imported intermediates, the nominal exchange rate may thus have important short-run supply-side effects, in addition to its standard demand-side effects. Intuitively, therefore, the real effects of devaluation will depend in general on the relative strength of the supply and demand responses.

Gylfason and Schmidt (1983) provide a formal analysis in which a nominal devaluation influences output both through the cost of imported inputs on the supply side and through trade flows and expenditure on the demand side. In particular, by decomposing the effect of devaluation into a demand effect and a cost or supply-side effect, they show that, even though the traditional Marshall-Lerner condition is met, their net effects on real income will depend on the degree of factor substitutability. The lower (higher) the elasticity of substitution between imported oil and labor inputs, the more likely is that a devaluation will reduce (increase) real income. This analysis may help in explaining why a nominal devaluation may have a short-run contractionary effect on output through its impact on the cost of imported inputs. The adverse effect of a devaluation on output may come from other channels as well, including through changes in interest rates, taxation, or on the domestic currency value of external debts (van Wijnbergen, 1986). The key lesson of this analysis is that contractionary effects induced by nominal exchange rate changes can be significant and thus may hamper the success of any macroeconomic stability programs.

\section{Exchange rate pass-through to inflation}

In the discussion of the role for monetary policy, it is important to distinguish whether the exchange rate matters to the extent that it is relevant for domestic inflation, or monetary authorities care about the exchange rate for reasons other than inflation. In either case, while always taking it into account in policy decisions, the monetary authorities may or may not decide to influence it depending on the perceived ability to do so systematically. For most industrial economies the exchange rate does not enter into the decisions of policymakers above and beyond the impact on expected inflation. In emerging market countries, by contrast, the exchange rate can play as an important instrument of policies 
for achieving domestic objective other than price stability, such as for promoting export competitiveness and protecting domestic industries, not only in countries with explicit exchange rate objectives but also in those that target inflation.

What determines the weight of the exchange rate in the monetary policy framework? A primary factor that is common to all frameworks is the impact of exchange rate movements on domestic inflation. Countries that experience high pass-through typically tend to put greater emphasis on the exchange rate in their monetary policy framework, as often encountered in countries that just move to more flexible exchange rate regime. In New Zealand, for example, the exchange rate played a particularly important role during the disinflation phase in 1988-93, when direct pass-through effects from the exchange rate to inflation were the strongest and best identified channel of monetary policy (Munro, 2004). Subsequently, a weakening exchange rate pass-through in an environment of low and stable inflation led to a shift of emphasis towards interest rate channels and the influence of the output gap. In the current medium term orientation of monetary policy, the exchange rate remains an important, though less significant, transmission channel for monetary policy. Similarly, Minella et. al. (2003) also highlights the importance of pass-through for the monetary policy framework during a crisis. In the turbulent years of 2001 and 2002, when Brazil was hit by domestic and external shocks with considerable impact on the exchange rate, the central bank aimed at minimizing the potential inflationary effects of the exchange rate depreciation and increases in administered prices. The main goal of monetary policy was to limit the propagation of the shocks to other prices of the economy.

For the Asian countries, Sahminan (2005), for example, estimates short-run and long-run exchange rate pass-through using co-integration method. He applies this for exchange rate pass-through into import prices in Indonesia, the Philippines, Singapore, and Thailand during the period from 1974 to 2000. The estimation results show that among the four countries only Singapore had incomplete exchange rate pass-through; the other three countries had complete exchange rate pass-through. The long-run exchange rate pass-through estimates are $0.880,1.179,0.163$ and 0.866 for Indonesia, the Philippines, Singapore and Thailand, respectively. The speeds of adjustment from the short-run deviation to the long-run equilibrium for the Philippines and Thailand are 0.532 and 0.178 , respectively. These results are much higher than the exchange rate pass-through estimates in Alba and Papel's (1998) paper. This is not surprising considering that these estimates are for the exchange rate pass-through into import prices while Alba and Papel's estimates are for the exchange rate pass-through into inflation. Nevertheless, the study gives some insight on the role of distribution and retailers, such as the presence of Multi-National Companies (MNCs) together with intrafirm trade, in dampening the inflation effect of the exchange rate changes in Southeast Asia in addition to differential in the inflation rates and money growth.

In general, however, there is evidence that the pass-through of exchange rate to inflation has been small and declining over the 1990s (Amato et. al., 2005). The decline has been associated with greater credibility of monetary policy, and the low and stable inflation environment and lower inflation expectations (Heath et al, 2004). Financial innovations and hedging against short-term exchange rate risks may also have reduced exchange rate pass-through. The underlying idea is that improved hedging possibilities allow importers and exporters to be covered against exchange rate risks and thus they would tend to ignore shocks that may turn out to be only temporary. In emerging market countries, the trend towards the adoption of more flexible exchange rate regime is also found to be important. As the exchange rate becomes more volatile, importers tend to 
view a change more often as temporary and therefore tend to change prices less frequently, e.g., by employing a certain "shadow" band of exchange rate movements for their price setting behavior.

Nonetheless, cares need to taken for the need of accurately measuring changes in pass-through in emerging market economies. Caputo and Tokman (2004), for example, argue that one reason why Chilean monetary policy makers have responded to exchange rate developments above and beyond what they imply for expected inflation is that they may have misperceived the extent and speed of the decline in pass-through. In particular, it is important to understand the transmission mechanisms of exchange rate changes, and in particular the role of the trade and investment channels. Empirical works are often conducted to distinguish the direct import price effect, the relative price effect (expenditure-switching), the intermediate effect (cost of input) and the balance sheet effect (currency mismatch) of exchange rate movements on consumer prices.

Several methodological issues are also important to be fully addressed in assessing exchange rate pass-through to inflation (Amato et. al, 2005). Firstly, one should make a clear distinction between short- and long-run pass-through effects, since the extent of short-term pass-through may be limited and incomplete while the long-run pass-through is usually almost complete. Secondly, there seems a potential asymmetry in exchange rate pass-through effects between appreciations and depreciations. Thirdly, exchange rate movements have effects on inflation but may in turn also be affected by inflation and real variables, indicating two directions of causality. Fourthly, while most papers focus on the average level of exchange rates, exchange rate volatility may have an impact on inflation and inflation volatility.

\section{Policy Responses: The Impossible Trinity?}

While explaining the heightened exchange rate volatility since the 1980's becomes the subject of a number of studies in the literature, other economists focus their attention on some policy issues that grew with it. The issues become increasingly complex and pressing with the boom and burst cycles of large and volatile cross-border financial flows emerging from unprecedented scope and speed of economic and financial globalization since the 1980's. With the recurrent of crisis in Latin America, Asia, and Russia, the policy issues for causing and mitigating the increasing vulnerability of a country to financial crisis have become the main agenda for discussions in the literature as well as among policy makers. What the origins and how these recurrent financial crises evolve and have deep impacts on the economy? How can a country design its foreign exchange regime, exchange rate system, and domestic macroeconomic policies for averting the risks against financial crisis while at the same time able to reap the benefits from these large and volatile capital flows?

While the early financial crises can be traced back as far as the nineteen century, the crises of the 1990s have fundamental differences in its close association with capital flows and wider and deep impacts on the economy which require prolonged recovery (Eichengreeen and Bordo, 2002). ${ }^{13}$ These financial crises have some common characteristics in that they are preceded by liberalization in banking and capital account,

\footnotetext{
${ }^{13}$ The early financial crises is commonly associated with crises such as exchange rate crisis of Argentina in 1885, banking crisis of Australia in 1893, etc. Most cited example of recent financial crises in the 2000s are of Latin America in 1982/83, Mexico crisis of Mexico 1994/95, and of Asia in 1997.
} 
large and volatile capital flows, and increasing burden of external debts especially in short-term maturity (Halliwood and McDonald, 2001, p 304). What more devastating nature of the twentieth century crises has been their unprecedented speed and scope, so that they have been more difficult to predict and be responded, and often be ignited by huge capital flow reversals and then escalated by herding behavior in the part of international investors. The recent crises have also proved to be more dangerous in that they often cause contagious effects to other countries that exhibit similar external vulnerabilities.

Whatever the explanations for the origins and impacts of the crises, they just show how macroeconomic policy in open economy with large and volatile capital flows has become increasingly more complex and difficult. It is often exposed to trilemma, commonly known as the impossible trinity, between the objectives of stabilizing exchange rate, benefiting from free capital flows, and maintaining policy independence for attaining domestic economic objective. Naturally, only two of these three objectives can be attained simultaneously. For example, a country that opts to enjoy free capital flows would need to let more flexible exchange rate movements for absorbing the volatility in the flows so as to be able to direct domestic monetary policy for attaining domestic objectives such as price stability and economic growth. In another instance, a country that prefers exchange rate stability such as that in fixed regime may have to adopt capital control to be able to limit the direct impacts of capital flows on the independence of domestic monetary policy for price stability and economic growth.

In practice, however, such a corner solution to the impossible trinity may not be appropriate for policy makers facing greater opportunity emanated from more open economy for domestic economic objectives. They may prefer to have more capital mobility and flexible exchange rate movement while at the same time still be able to manage and direct its policy for domestic price stability and economic growth. In this case, the general policy responses for mitigating the impossible trinity comprises of three instruments, i.e. foreign exchange intervention for stabilizing exchange rate, some form of capital account measures for minimizing the negative impacts of short-term capital flows to the economy, and strengthening monetary policy through inflation targeting framework for attaining price stability. The specific mixture and depth of these instruments would certainly depend on the specific nature and conditions of the respective country, especially those of emerging economies. .

Foreign exchange intervention becomes an option of monetary policy response for stabilizing exchange rate, especially those adopting flexible regime. Exchange rate may deviate substantially from its values implied by fundamentals in the short-run, even in the well functioning foreign exchange market (Sarno and Taylor, 2002). As such, the disconnect between short-term exchange rate levels and macroeconomic fundamentals create a role for intervention (Krinjenko, et. al., 2003). In particular, intervention may be used, possibly in conjunction with monetary policy, to stabilize market expectations, calm disorderly market, and limit unwarranted short-term exchange rate movements because of temporary shocks. Intervention also may be used in conjunction with policies to redress macroeconomic imbalances. Nonetheless, intervention is not an independent policy tool as its effectiveness is conditional upon the consistency of targeted exchange rates with macroeconomic policies especially under high capital mobility. In particular, intervention would unlikely be effective when adverse exchange rate movement reflects persistent macroeconomic imbalances. Large capital flows or fragility in the financial sector, for example, may require adjustments in several sectors, including the exchange rates, interest rates, and fiscal policies. 
The use of capital controls has regained renewed interest as a possible policy response after the wake of Asian crisis. In some countries the structure of capital controls is pervasive and appeared to be a legacy from the past, while other countries use capital control as active instruments for macroeconomic and structural policies. Using a sample of 45 countries, Johnston and Tamirisa (1998) indicate that balance of payments and macroeconomic management, market and institutional evolution, prudential, and other factors are important in explaining countries recourse to capital controls. ${ }^{14}$ Nonetheless, there are significant differences of these factors in explaining controls on inflows, outflows or different types of capital account transactions. For example, macroeconomic management appears primarily to motivate control on capital inflows, while balance of payments conditions motivate controls on both inflows and outflows. Likewise, weak regulatory and financial repression explain most types of capital controls, while strengthening domestic institutional and market structure appears to be the main reasons for regulating operations relating to banking and international investors. They conclude that the design of capital account liberalization programs require proper understanding on how these factors effective in mitigating the risks from increasing large and volatile capital flows to domestic economic objectives.

Inflation targeting framework (ITF) has also been proposed for enhancing the independence of monetary policy for domestic price stability. In comparing the experience of 12 emerging market inflation targeters with that of six of their industrial country counterparts, Ho and McCauley (2003) made the following interesting observations. First, emerging market economies tend to be relatively more exposed to exchange rate fluctuations, in particular since they are still in the relatively early stages of accommodating greater exchange rate flexibility. In the longer run, however, improved inflation outcomes, consolidation of policy credibility and economic development can be expected to help reduce some of the vulnerabilities of emerging market economies. Second, under inflation targeting in particular, exchange rate considerations can be expected to play a prominent role in emerging market economies, given the substantial influence of the exchange rate on inflation in these economies. Third, the emerging market inflation targeters have in practice responded flexibly to the various challenges posed by exchange rate fluctuations, using not only monetary policy but sometimes also direct instruments for stabilizing exchange rates. Finally, none of the above should be taken to suggest that the cost of exchange rate movements and the policy attention thereto are relevant only to emerging market economies. Recent experience reminds us that having to keep an eye on the exchange rate is also a fact of life in industrial economies, inflation targeting or not.

\section{Concluding Remarks}

This paper reviews theoretical and empirical perspectives pertaining to the nature and impacts of exchange rate movements on macroeconomic conditions, and how these have fundamental ramifications on macroeconomic and monetary policies. In particular,

14 BOP and Macroeconomic management reasons to include: (i) weak BOP condition, (ii) shortage domestic saving, (iii) policy autonomy, (iv) asymetric information problem, (v) protecting fixed regime, (vi) financial repressed economies. Market and institution evolution factors include: (i) protect infant industry, (ii) second best solution, (iii) effectiveness of direct credit and interest rate control. Prudential reasons: (i) minimize different international risks, (ii) preserve systemic stability. Other factors: economic size, openness, social or political. 
we show that, with increasing speed and scope of financial globalization and crossborder capital flows, the view on exchange rate has been changing from trade flows to modern financial asset views. The focus of thinking in both theory and policy has also shifted toward explaining exchange rate volatility, choice of exchange rate regime, benefits and costs of capital flows, financial crisis, and monetary policy response under flexible exchange rate regime.

Even though no single theory can best explain exchange rate movements for all country and or for all period, they provide inferences for policy measures for addressing key fundamental factors driving exchange rate in the long-run, i.e. inflation, exchange rate, money supply, real output, as well as preferences in holding of currencies and financial assets. Nonetheless, exchange rate may exhibit short-run volatility from its fundamental level due to a number of reasons, e.g. productivity shocks, risk premia, stochastic money supply, inconsistency between monetary policy and exchange rate regime, and portfolio shifts and speculations in the financial market. As such, programs for exchange rate stabilization should thus be directed towards resolving both these fundamental factors as well as short-run volatility.

With the recurrent of financial crises in emerging economies, macroeconomic policy in open economy has become increasingly more complex and difficult with large and volatile capital flows. Policy makers are often exposed to trilemma, commonly known as the impossible trinity, between the objectives of stabilizing exchange rate, benefiting from free capital flows, and maintaining policy independence for attaining domestic economic objective. In practice, however, policy makers may prefer to have more capital mobility and flexible exchange rate movement while at the same time still be able to manage and direct its policy for domestic price stability and economic growth. In this case, the general policy responses for mitigating the impossible trinity comprises of three instruments, i.e. foreign exchange intervention for stabilizing exchange rate, some form of capital account measures for minimizing the negative impacts of shortterm capital flows to the economy, and strengthening monetary policy through inflation targeting framework for attaining price stability. The specific mixture and depth of these instruments would certainly depend on the specific nature and conditions of the respective country, especially those of emerging economies. .

\section{References}

Alba, J.D., and Papell, D. (1998). "Exchange Rate Determination and Inflation in Southeast Asian Countries." Journal of Development Economics, 55, 421-437.

Amato, J., Filardo, A., Galati, G., von Peter, G., and Zhu, F. (2005), "Exchange rates and monetary policy: an overview", BIS Working Paper, Juni.

Caputo, $\mathrm{R}$ and A Tokman (2004): "Exchange rates and monetary policy: Some relevant issues discussed at the Central Bank of Chile", paper presented at BIS Autumn Economists' Meeting, 28-29 October, Basel.

Cheung, YW, Chinn, M, and Pascual, AG (2004), "Empirical Exchange Rate Models of the Nineties: Are Any Fit to Survive?", IMF Working Paper No. WP/04/73.

Dornbusch, R. (1976), "Expectations and Exchange Rate Dynamics", Journal of Political Economy, 84, pp. 1161-76. 
Dornsbusch, R. and S. Fischer (1980), "Exchange Rates and the Current Account", American Economic Review, 70, pp.960-71.

Edison, H, J. Gagnon and W. Melick (1997): "Understanding the empirical literature on purchasing power parity: the post-Bretton Woods era", Journal of International Money and Finance, vol 16, no 1, pp 1-17.

Ho, C. and McCauley, R.N. (2003), "Living with flexible exchange rates: Issues and recent experience in inflation targeting emerging market economies", BIS Working Papers No 130, Monetary and Economic Department, Februari.

Ehrmann, M. dan Fratzscher, M. (2004), "Exchange Rates and Fundamentals: New Evidence from Real-Time Data", ECB Working Paper Series No. 365, Mei.

Eichengreeen, B. and Bordo, M.D. (2002), "Crises Now and Then: What Lessons from the Last Era Globalization?", NBER Working Paper Series No. 8716, January.

Frenkel, J.A. (1978), "Purchasing Power Parity Doctrinal Perspectives and Evidence from the 1920s", Journal of International Economics 8, pp. 169-91.

Frenkel, J.A. and R.M. Levich (1975), "Covered Interest Arbritrage: Unexploited Profits", Journal of Political Economy, 83, pp. 325-38.

Froot, K.A. and R.H. Thaler (1990), "Foreign Exchange", Journal of Economic Perspectives 4(3), pp. 179-92.

Galati, G. and Ho, C. (2001), "Macroeconomic News and Euro/Dollar Exchange Rate", BIS Working Papers No. 105, December.

Gartner, M. (1993), Macroeconomics Under Flexible Exchange Rate, Manchester: Harvester Wheatsheaf

Girton, L. and Roper, D. (1981), "Theory and Implications of Currency Substitution", Journal of Money, Credit, and Banking, 13, pp. 12-30.

Hallwood, P.C. dan McDonald, R. (2001), International Money and Finance, 3rd edition, Cambridge: Blackwell Publisher

Heath, A, I Roberts and T Bulman (2004): "Inflation in Australia: measurement and modelling", in C Kent and S Guttmann (eds), The Future of Inflation Targeting, Reserve Bank of Australia.

Hodrick, R.J. (1987), The Empirical Evidence on the Efficiency of Forward and Futures Foreign Exchange Markets, Chur: Harword.

Isard, J.C. (1978), "Exchange Rate Determination: A Survey of Popular Views and Recent Models", Princeton University Essay in International Finance, 42.

Johnston, BJ and Tamirisa, MT (1998), "Why Do Country Use Capital Controls?", IMF Working Paper No. WP/98/181, December.

King, D.T., Putnam, B.H. and Wilford, D.S. (1977), "A Currency Portfolio Approach to Exchange Rate Determination", in. The Monetary Approach to the Balance of Payments, New York: Praeger.

Krinjelnko, JIC, Guimares, R, and C Karamadag (2003), "Official Intervention in the Foreign Exchange Market: Elements of Best Practices", IMF Working Paper No. WP/03/152, Juli 
Kurniati, Y. dan Hadiyanto, A.V. (2002), "Rupiah Exchange Rate Behaviour and Alternative Calculation of Equilibrium Exchange Rate", Bulletin Ekonomi Moneter dan Perbankan, Vol. 5 No. 1, Juni.

Lewis, K (1995), "Puzzle in International Financial Markets" in Handbook of International Economics, G. Grossman and K. Rogoff (eds), Amsterdam: Elsevier.

Levi, M. (1990), International Finance, $2^{\text {nd }}$ Edition, NY: Mac Graw-Hill Publishing Company.

Lyons, R K (2001): The Microstructure Approach to Exchange Rates, MIT Press.

MacDonald, R. (1988). Floating Exchange Rates: Theories and Evidences. London: Unwin-Hyman.

Meredith, G. and Y. Ma (2002), "Forward Premium Puzzle Revisited", IMF Working Paper No. WP/02/28, February.

Minella, A, P de Freitas, I Goldfajn and M Muinhos (2003): "Inflation targeting in Brazil: constructing credibility under exchange rate volatility", Central Bank of Brazil Working Paper no 77, July.

Munro, A (2004): "Exchange Rate Dynamics: the New Zealand Dollar", Reserve Bank of New Zealand Economics Department, RBNZ Paper.

Mussa, M. (1979), "Empirical Regularities in the Behavior of Exchange rates and Theories of Foreign Exchange Market" in Brunner, K. and Meltzer, A.H. Policies for Employment, Prices and Exchange Rates, Carnegie-Rochester Conference Series on Public Policy.

Officer, L.H. (1982). Purchasing Power Parity and Exchange Rates: Theory, Evidence, and Relevance. Greenwich, CT: JAI Press.

Rogoff, K., Froot, KA, and Kim, M. (2001), "The Law of One Price After 700 Years", IMF Working Paper WP/01/174

Sahminan (2005), "Exchange Rate Pass-Through into Import Prices in Major Southeast Asian Countries", Bank Indonesia, mimeograph. September.

Sarno, L and M P Taylor (2001): "The microstructure of the foreign exchange market: a selective survey of the literature", Princeton Studies in International Economics, vol 89.

Williamson, J. (1994), Estimating Equilibrium Exchange Rates. Washington, DC: Institute for International Economics.

Sodersten, B. (1980). International Economics. New York: St Martin Press.

Reinhart, C.M, (1995), "Devaluation, Relative Prices, and International Trade: Evidence from Developing Countries", IMF Staff Papers 42 (June), pp. 290-312.

Senhadji, A. (1998), "Time Series Estimation of Structural Import Demand Equations: A Cross-Country Analysis", IMF Staff Papers 45, June.

Agenor, P-R. (2000). The Economics of Adjustment and Growth. New York: Academic Press.

Gylfason, T. and M. Schmidt (1983), "Does Devaluation Cause Stagflation?" Canadian Journal of Economics 16, November, pp. 641-54. 
van Wijnbergen, S. (1986)."Exchange Rate Management and Stabilization in Developing Countries", Journal of Development Economics 23 (October), pp. 227-47. 